\title{
Narrative Research on Shanghai-style Ceramics
}

\author{
Qiang Zhao, Mingyi Zhou, Geng Huang* \\ Donghua University \\ Shanghai, 200051
}

\begin{abstract}
This paper analyzes Shanghai-style ceramics by taking Shanghai-style ceramic culture and work as the research object, and from the basic symbolic creative elements and carriers, the creative styles and environment under cultural background, plot extended product functions and experience and so on, narrative theories are taken as guidance, This paper interprets Shanghai-style ceramics by studying the morphological, sequential and emotional narration techniques, and finds out the new direction to develop Shanghai-style ceramics, which will become a new force to drive the development of Shanghai-style culture.
\end{abstract}

Keywords-Shanghai-style ceramics; Shanghai-style culture; Narratology; Narrativity

\section{INTRODUCTION}

The inclusiveness of Shanghai-style ceramics has made it a complicated art. It has integrated with multi-regional art, collided with multiple thinking, and blended with multiple contexts. Shanghai-style ceramics are not only restricted to Shanghai Region, but also the complicated cultural background that combines Jiangnan culture and western thoughts, and both the scope characteristics and behaviors are complicated. Narratology refers to narrating an event, and reconstructing this event by languages, texts, graphs and other modes. In 1960s, narrative theories were found in literary researches and criticism in names of "narrative structure analysis", "narrative grammar", "narrative semiology", "narrative poetry", "prose poetry", "narrative remarks", etc. After that, narrative study has been developed in design, art, architecture, pedagogy, etc. Therefore, the study of Shanghai-style ceramics can regard narratology as the theoretical guidance, and narrative language symbols as the basis to deconstruct and analyze Shanghai-style ceramics, focus on narrative perspective, narrative mode, narrative environment, narrative scenarios and other cultural background and functions, structure, behaviors and other ceramic product functions. Under western cultural thoughts, the narrative research of Shanghai-style ceramics has expanded the narrative scope and degree of Shanghai-style ceramics, and made the design expression effect and connotative expression of ceramic products richer. Based on the aforementioned contents, narratology can be used to interpret Shanghai-style ceramics under narrative characteristics from the occurrence of narrative and design behaviors as well as the development trend of Shanghai-style ceramics.

\section{DEVELOPMENT AND SOURCE OF SHANGHAI-STYLE CERAMICS}

"Shanghai-style" is originated from Shanghai Painting School in Daoxian Year, and then extended to literature, film, construction, ceramics and other cultural art fields with Shanghai-style painting. "Shanghai-style" becomes a regional call, and refers to the unique features and characteristics of Shanghai. In 1843, Shanghai opened treaty ports, and European modern industrial civilization and thoughts were flooded into Shanghai, collided with traditional culture in Shanghai and formed special Shanghai-style culture. Shanghai-style culture has also become a cultural phenomenon generated in the special social environment of Shanghai in the modern times. "Shanghai-style" was originated from Shuduan-Nengpin in Tang Dynasty. Scholars and painters have not only absorbed the unique style of Shanghai-style painting, but also integrated different era characteristics and regional characteristics, and the porcelain painting styles have exerted constant influence on Shanghai-style painters, and the development phase can be divided into: Three phases, including Shanghai painting school, Shanghai-style painting and Shanghai-style culture. Lay an important foundation for developing Shanghai-style ceramics.

In the 20th century, science and technologies have been developed, and art has been reformed. Meanwhile, western ideology and culture has been transmitted to all fields, and "Shanghai-style" has been gradually applied in more fields. Wherein, ceramic art has also constantly collided with western modernized ceramic artistic thoughts. In order to adapt to business requirements and the hobbies of audiences, Shanghaistyle ceramics have made bold breakthroughs and innovations. Shanghai-style ceramic art is bold and rich in the spirits of the times, emphasizes on innovation and personality, and is different from traditional ceramics. 
TABLE I DEVElopment Course OF ShanghaI-STyle CERAMics

\begin{tabular}{|c|c|c|c|}
\hline Period & Major events & Important figures & Achievements \\
\hline \multirow{3}{*}{ Sprouting period } & $\begin{array}{c}\text { "Ceramic Industry Art Research Club" was established in } \\
1992\end{array}$ & $\begin{array}{c}\text { Qi WANG acted as Deputy President of } \\
\text { the research club, and Dafan WANG } \\
\text { acted as the member }\end{array}$ & \multirow[t]{2}{*}{$\begin{array}{c}\text { Exhibition communication, } \\
\text { painting album printing and skil } \\
\text { teaching }\end{array}$} \\
\hline & & $\overline{\text { Yeting WAI }}$ & \\
\hline & "Full Moon Conference" was established in 1928 & $\begin{array}{c}\text { WANG, Bishan DENG, Zhongnan XU, } \\
\text { Hexian TIAN, Yiting CHENG, and } \\
\text { Yucen LIU[1] }\end{array}$ & $\begin{array}{c}\text { Combination of Shanghai-style } \\
\text { Painting and Ceramics }\end{array}$ \\
\hline \multirow[b]{2}{*}{ Growth stage } & $\begin{array}{l}\text { The first porcelain making kiln, "Jiangwan Kiln" was } \\
\text { established in } 1996 \text { in Shanghai }\end{array}$ & Jialiang SHEN & \\
\hline & $\begin{array}{l}\text { From } 1996 \text { to } 1997 \text {, a batch of famous painters in } \\
\text { Shanghai jointly explored and exchanged experience in } \\
\text { ceramics culture at Jiangwan Creative Base }\end{array}$ & $\begin{array}{c}\text { Jialiang SHEN, Guiming ZHANG, } \\
\text { Zhengxin YANG, Peichu ZHANG, and } \\
\text { Peicheng ZHANG }\end{array}$ & Thousands of work \\
\hline \multirow[t]{2}{*}{ Formative period } & $\begin{array}{l}\text { From } 1997 \text { to } 1998 \text {, Shanghai-style ceramics "Fire Art } \\
\text { Salon" was gradually formed }\end{array}$ & $\begin{array}{l}\text { Jialeng CHEN, Jialiang SHEN, Xiaofu } \\
\text { YU, Azhong HUANG, Hongtao LIANG, } \\
\text { Demin XU el al. }\end{array}$ & $\begin{array}{l}\text { The work was exhibited in } \\
\text { Shanghai "Baiyulan" Square. }\end{array}$ \\
\hline & $\begin{array}{l}\text { Jingpin LUO founded "Shentao" at Jiangqiao Riyong } \\
\text { Road [2] in } 1999\end{array}$ & Jingpin LUO & Shanghai-style artistic ceramics \\
\hline Innovation phase & $\begin{array}{l}\text { All Shanghai-style ceramics exhibitions from } 2000 \text { to the } \\
\text { present }\end{array}$ & $\begin{array}{l}\text { Jialeng CHEN, Guoxing JIANG, Qiang } \\
\text { ZHAO, Hegen KE, Qiang XIE, and } \\
\text { Youyu LI et al. }\end{array}$ & $\begin{array}{l}2018 \text { Shanghai-style Ceramic } \\
\text { Artist Work Exchange, etc. }\end{array}$ \\
\hline
\end{tabular}

\section{NARRATIVE ELEMENT RESEARCH ON SHANGHAI-STYLE CERAMICS}

The narratology of Shanghai-style ceramics is based on "narrative" approaches to analyze, interpret and develop Shanghai-style ceramics works. Narratology in Shanghai-style ceramics is to make the external objects and audiences of Shanghai-style ceramics consistent in inner feelings by virtue of narrative design techniques. This is Shanghai-style ceramics generated after reinterpretation under the influence of western thoughts, and many ceramics can show different styles and elements, but as for its narrative elements, it can be summarized as the basic symbolic creative elements and carriers, the creative styles and environment under cultural background, plot extended product functions and experience, etc.

\section{A. Basic symbolic creative elements and carriers}

The picture elements created in Shanghai-style ceramics works center on the narrative source and behaviors of Shanghai-style ceramics. Shanghai-style ceramics can extract picture elements from utensils, techniques, music, drama, dancing, folk customs, lifestyles, figure images, plant and animal images, cultural stories, architectural symbols, regional characteristics, natural resources, and other perspectives. The forms of creative elements and carries can be one-dimensional or multi-dimensional, but they are finally represented in a symbolic mode. Water Color series of works created by Qiang ZHAO, Contemporary Shanghai-style Ceramic Artist extracted water corrugated symbols, and then implemented constant repeat added with the gradation in different colors. It has represented the traditional enjoyable and lasting appeal, and also showed the ordered and rational aspect of modernized deconstructing art.

Based on the deconstruction extraction symbols of narrative color, form, functions and other aspects, Shanghai-style ceramics recreate symbol information into new Shanghai-style ceramics work symbols. Artists regard the created picture elements and pattern of manifestation as symbols, and realize the perfect integration of Shanghai-style and elements by extracting and sublimating elements.

\section{B. Creative styles and environment under cultural situations}

Cultural background is the narrative background and timespace relationship for Shanghai-style ceramics, which will also influence the creative styles and environment of Shanghai-style ceramics. Culture is also the core of national spirits, and Shanghai-style culture has integrated both Chinese and Western cultural thoughts, and is the culture formed by fully integrating time and regions as well as other elements of all parties based on Chinese civilization. The creative styles of an art work is the presentation of its overall visual language. It can reflect the lifestyle and characteristics of the user, and has the group characteristics of users. The cultural background of Shanghai-style ceramics has absorbed western thoughts and cultures, and integrated Shanghai time and regional characteristics, and recorded the development records of Shanghai-style ceramics culture in details. It has shown the long-lasting histories and cultures about the development of Shanghai-style ceramics. Shanghai-style Ceramic Artist Hegen KE grew up along Jiangnan Coastal Regions. This beautiful, lush, gorgeous, moist and warm land is the basement for him to grow up, and has given him the inspirations to create meaningful masterworks. His Buddha in All Forms series has combined traditional Chinese spiritual culture of paying respect for the Buddha and western modernized creative techniques, well applied high-temperature colored glaze and abstract decorative techniques, to express "sufficiency" and "comfort", which is quite extraordinary.

New Shanghai-style ceramics are basically based on performance-style retro themes, geometrical topics of abstract graphics and lines and representational topics relevant to life, etc. In General: Based on the cultural context of the current creative economic era, the narrative characteristics for creative styles of Shanghai-style ceramics are mainly divided as follows: Fashion, creativity and popularization. 


\section{Plot extended product functions and experience}

Plot extended product functions and experience are also the foundation for artistic creators to narrate to users. It serves users with certain plot extended functions in the end based on cultural background by symbolic languages, and finally Shanghai-style ceramics products can exert more functions. As the combination of culture and products, Shanghai-style ceramics is based on the plot extended product functions and experiences of narratology, and has also brought narrative experience to users of Shanghai-style ceramic art products, increased the cognition of users about Shanghai-style ceramics culture.

Shanghai-style ceramics under narratology tell stories through functions and experience, and make users receive plot information through experiencing ceramics products unconsciously. The creation of Shanghai-style ceramics will be regarded as the media for the plot, and the plot will go deep into Shanghai-style ceramics. Shanghai-style ceramics have various functions and experience modes under narrative plot extension, ranging from one-dimensional to multi-dimensional mode, geometrical to organic mode, simple material to the combination of several materials. For instance, the ceramic art work, Chair series created by Guanghui CHEN used different materials and types of industrial products to form the chair. This work has been endowed with the implied meaning of social hierarchy in the society, with strong significance of sociology.

\section{STUDY ON THE NARRATIVE TECHNIQUES FOR SHANGHAI-STYLE CERAMICS}

\section{A. Morphological narration}

Shanghai-style ceramics can build the relationship between works and narrative themes by the morphological characteristics of ceramics works. It is a technique of expression to narrate based on the material color of morphological characteristics. Besides, it has also considered whether the user group can feel the stories and significance expressed behind the work. Morphological narration is firstly originated from basic morphological narration. By the basic form, we can directly extract the form or structural characteristics, and then describe Shanghai-style ceramic products by referring to narrative techniques. For instance, the work called Prosperity in 2019 Shanghai Shanghai-style Ceramic Art Work Exchange was created based on pig modeling. "Pig" is endowed with auspicious implies of ample food and clothing as well as a peaceful and content life based on its plump, gentle, honest and tolerant form. By extracting the cute animal form, and applying the narrative technique of zoosemy transference, it is aimed to transmit the culture of Shanghai-style ceramic work.

Generally, morphological narration is static and should be adopted together with the environment. Such narrative modes are mostly used to express memories and reflections by modeling, tell stories by the model formed by language, and open the connection between people and Shanghai-style ceramic works [3].

\section{B. Sequential narration}

Sequential narration techniques can be visual sequential modes similar to visual characteristics, and unified pattern colors will form the unified common characteristics of Shanghai-style ceramic works, reflect the overall narrative transmission advantages and deepen the perception of users. Sequential narration techniques can also be the mode of expression for continuous visual sequence. The powerful amount of information can also leave a deep impression on people who are seeing it. This is similar to "the flash reading of pictures". Sequential expression can narrate the powerful amount of information behind the work, and make people see clearly at a glance.

Narrative Shanghai-style ceramics are visual, imaged and participatory events that are changing at any time. The sequential narration techniques are to form the same vision for the same series of Shanghai-style ceramics, and increase the degree for people to recognize it. The most common mode of sequential narration is parallelism and repetition. The effect is to emphasize and highlight the narrated objects by the same elements in a consciously repeated using process. Sequential narration technique is the expression to emphasize the expressed events. This process can be the repetition of single behaviors and actions or the continuous occurrence of certain event, and can constantly deepen people's understanding about Shanghai-style ceramic works by repeating words and pictures like advertising.

\section{Emotional narration}

"Narration" refers to summarizing manufacturing significance by personal experience and reflection. Shanghaistyle ceramic artists can narrate Shanghai-style culture and history information behind their works to audiences by emotional resonance based on their personal creations, and this activity behavior can be of important significance. Shanghaistyle ceramics are created by emotional narration technique, which can make the single ceramic products three-dimensional. On one hand, this can increase the emotional experience of users about Shanghai-style cultural and historical memories, and make them feel the cultural information unconsciously. On the other hand, Shanghai-style ceramic works integrate the emotion and actual objects of Shanghai-style culture and can both display and transmit Shanghai-style culture. By the expression of emotional narration, Shanghai-style culture and Shanghai-style ceramic culture can be better promoted.

The emotional narration technique has increased people's emotional experience for the historical and cultural memories of Shanghai-style ceramics, made Shanghai-style ceramic works have more connotation and deeper sense. Meanwhile, the plasticity can be fully exerted in the creation and expression of Shanghai-style ceramics. As a Shanghai-style ceramist, Qing KANG narrated her emotional memories and feelings about the mud and the creation of Shanghai-style ceramics by the display mode of specimen notes, to help you read the work of an artist in a better way. The work of Ruyi is reflected by combining Chinese classic plane patterns with western cubism. In this work, plant patterns are used as elements, combined with Shanghai-style decoration culture, to realize a more vivid picture, and better transmit Chinese classic wishful culture and 
Shanghai-style decoration device culture. We are now living in an era of perceptual consumption. Qing KANG injected her own emotional perceptions about culture and plants in her works by emotional narration technique, and with the emotional principle running through Shanghai-style ceramic works, this can better fit the trend of modernized ceramics.

\section{CONCLUSION}

Shanghai-style culture is the direct source to create Shanghai-style ceramics, and Shanghai-style ceramics under narrative characteristics are also the new force to inherit Shanghai-style culture. Shanghai-style ceramic researches can be carried out based on Shanghai-style ceramics under narratology from the basic symbolic creative elements and carriers, the creative styles and environment under cultural background, plot extended product functions and experience, and other narrative elements, and can be divided into morphological narration, sequential narration and emotional narration. Interpretation of Shanghai-style ceramics in a narrative mode can fully explain the connotation of Shanghaistyle ceramics and Shanghai-style culture, and reflect the development direction of Shanghai-style ceramics:

(1)Realize mutual penetration with other disciplines. By blending with modern and contemporary culture, Shanghaistyle ceramic art should break through single discipline mode, be applied in other disciplines, and lay a foundation for the prosperous development of ceramic art;

(2)Carry out international exchange and cooperate in development. Break through the pure regional restrictions of Shanghai-style ceramics and realize internationalization. The occurrence of network exchange platforms as well as the generation of international art exhibitions, and international festivals are all the important manifestation of Shanghai-style ceramics to go international, and have also provided a suitable soil to form "new Shanghai-style" ceramics.

(3)Combine with emerging technologies. The development of Shanghai-style ceramic art has combined with the art of science and technology, such as virtual image and digital production as well as other digital media. By combining Shanghai-style ceramics with all types of composite materials, the artistic development of Shanghai-style ceramics can develop towards a higher and deeper level.

(4)Cultivate modernized creative talents of Shanghai-style ceramics. We should master traditional Shanghai-style ceramic techniques, while integrating contemporary elements, so that Shanghai-style ceramic techniques can be inherited and developed better, and this can be quite significant to cultivate the foundation of Shanghai-style ceramic culture, maintain the diversity and creativity of Chinese ceramic culture and promote the diversisfied development of ceramic culture.

Under the cultural confidence and artistic innovation history, the development of Shanghai-style ceramics will bring new development attitude to the inheritance and development of Shanghai-style culture, gather the cultural memories and visual symbols of Shanghai city, and become the new force to develop Shanghai-style culture.

\section{ACKNOWLEDGMENT}

Fund project:

(1)Shanghai Design Science Category IV Peak Discipline Funding Project-Fashion and Innovation Services and System Design Research Team-DD18002.

(1)Shanghai-style Crossover Art Research Base Project Funding in Donghua University (Shanghai Straddling Art research base of Donghua University)

Author brief: Qiang ZHAO (1970-), male, Jiangsu native, associate professor of the Fashion and Design College of the Donghua University, mainly engages in ceramic art design and creation.

Mingyi ZHOU (1995-), female, Hunan native, Master of the Fashion and Design College of the Donghua University, mainly engages in ceramic art and design research.

Corresponding author: Geng HUANG (1980-), male, Hebei native, Master, associate professor of the Fashion and Design College of the Donghua University, mainly engages in urban renewal and design research.

\section{REFERENCES}

[1] Ye CHEN. Inheritance and Development: Transmutation of Shanghai style Culture in a Century [J]. Journal of Jiaxing University, 2015(5) $65-76$.

[2] Jialu SHEN. Jingpin LUO: Artistic Life of Furnace Transmutation [J]. Masters and Master Works, 2016(5): 87-93.

[3] Haiming YAN. Museum and Collective Memory--knowledge, Identification and Remarks [J] Chinese Museum, 2013(3): 14-18.

[4] Fuming YUN. Transmitter of Shanghai-style Ceramic Art--Abou Famous Ceramist Jialiang SHEN [J]. Shanghai Artist, 2008(02): 54-57

[5] Aihong WANG, and Shiping LIU. Research about the Development of Cultural and Creative Products of Narrative Ceramics [J]. China Ceramics. 2019, 55 (01): 80-83.

[6] Hongwei SHI. Integration of Model and Color--Research about the Internal Rules of Innovation in Shanghai Ceramic Art[J]. China Ceramics, 2019, 55 (02): 85-90.

[7] Hongwei SHI. Discussion about the Development of Shanghai-style Ceramics from the Perspective of Original Ceramic "Wind Indicator"-Research about the Development and Current Status of Shanghai-style Ceramics[J]. Ceramic Research, 2018, 33 (05): 102-105. 